\title{
Egg Yolk Colour Depends upon the Composition of the Feeding Mixture for Laying Hens
}

\author{
P. DVOŘÁK, E. STRAKOVÁ ${ }^{1}$, J. KUNOVÁ, V. KUNOVÁ \\ Department of Biochemistry, Chemistry and Biophysics \\ ${ }^{1}$ Department of Nutrition, Animal Breeding and Animal Hygiene \\ Faculty of Veterinary Hygiene and Ecology \\ University of Veterinary and Pharmaceutical Sciences Brno,
}

Czech Republic

Received May 5, 2006

Accepted October 20, 2006

\begin{abstract}
Dvořák P., E. Straková, J. Kunová, V. Kunová: Egg Yolk Colour Dependis upon the Composition of the Feeding Mixture for Laying Hens. Acta Vet Brno 2007, 76: 121-127.

The aim of this study was to verify the possibility of replacement of fish meal by specially treated meal made of yellow lupin seed in relation to the yolk colour. The experiment was performed with 72 laying hens divided into two groups. The experimental group including 36 laying hens received a feeding mixture containing meal made of yellow lupin seed (the JUNO variety) which replaced fish meal used as an animal protein component in feeding mixtures in the control group. Samples of eggs were collected monthly in the course of seven months to determine the colour of egg yolk.

Yolk colour was determined by the spectrophotometric method using the CIELAB system. Measurement with the exclusion of gloss was carried out using a portable spectrophotometer. The average values of parameter $L^{*}$ decreased significantly $(\alpha=0.05)$, which confirmed the darkening of eggs. Parameters a* showed a significant increase (ANOVA $\alpha=0.01$ ), whereas the differences in the individual months ranged from 1.1 to 3.9. Yolk had distinct red-orange colour. Parameters $b^{*}$ did not show significant differences, however, the yolk tended to have an intensive yellow colour.

The presence of yellow lupin seed meal in the feeding mixture resulted in a more distinct yellowred colour of egg yolk.
\end{abstract}

CIELAB, lupin seeds, pigments, food colour, spectrophotometer, fish meal

There are a number of parameters indicating the quality of eggs intended for human consumption that can be affected by various external and internal factors, as reported by Tůmová and Ebeid (2005); B ain (1992); Halaj et al. (1998) and other authors. Egg yolk colour is one of major parameters linked to consumer requirements concerning eggs. Much effort of egg producers focuses on the use of suitable feeds to obtain the distinct tone of egg yolk colour. It is connected with the requirements of egg processors on the more intensive yellow- orange colour during the production of mayonnaises, confectionary corpuses or egg pasta. Yolk colour is particularly affected by the presence of pigments in some feeds, as reported by Leeson and Summers (1997). These pigments can be natural vegetable compounds such as xanthophyls (oxygen derivatives of carotenoids). Because of their low stability, natural pigments (Surai et al. 1998) are being replaced with synthetic ones that have been approved as additives to feeding mixtures for laying hens (Act No. 91/1996; Act No. 244/2000). This particularly concerns yellow ethylester of apocarotenic acid or red cantaxantine. The required tone of the egg colour is achieved by combining these pigments. Current trends in food safety aim at replacing synthetic products in animal nutrition, focusing mainly on the use of natural pigments. Therefore the aim of this study was to verify the possibility of replacement of fish meal by specially treated meal made of yellow lupin seed in relation to the yolk colour. For this purpose, the following original method was applied.

\footnotetext{
Address for correspondence:

Doc.MVDr. Petr Dvořák, CSc.

Department of Biochemistry, Chemistry and Biophysics

Faculty of Veterinary Hygiene and Ecology

University of Veterinary and Pharmaceutical Sciences Brno

Palackého 1-3, 61242 Brno, Czech Republic
}

Phone: +420 541562608

E-mail: dvorakp@vfu.cz

http://www.vfu.cz/acta-vet/actavet.htm 
The perception of colour depends on the chemical and physical properties of egg yolk, the quality and intensity of light emitted by the light source and on the particular observer. Egg colour can be assessed visually by comparing with The Yolk Colour Fan ${ }^{\circledR}$ (Roche) scale, as reported by Halaj et al. (1998). This scale was established by colorimetry and determined in the 3D colour diagram according to CIE (Commission Internationale de l'Eclaraige).

However, the surface colour of food can also be determined instrumentally using portable measuring devices (Dvořák et al. 2001; Dvořák et al. 2005) such as spectrocolorimeters with predefined parameters $\left(\mathrm{d} / 8^{\circ}\right.$ spherical geometry, $\mathrm{D}_{65}$ light source, the standard angle of the observer being $10^{\circ}$ and variable diameters of the opening, e.g. $8 \mathrm{~mm}$ ). The results are expressed as values $\mathrm{L}^{*}, \mathrm{a}^{*}$, and $\mathrm{b}^{*}$ according to the International Colorimetric System (CIE 1986). Calibration is based on the black $\left(\mathrm{L}^{*}=0\right)$ and white $\left(\mathrm{L}^{*}=100\right)$ standards.

\section{Materials and Methods}

Laying hens (ISA BROWN hybrid combination) were reared individually using cage technology in the accredited experimental enclosure of the Institute of Nutrition, Animal Breeding and Animal Hygiene, under conditions complying with the requirements specified in technological instructions for the rearing of this kind of hybrid combination laying hens. A total of 72 hens included in the experiment were divided into two groups (A and B), each consisting of 36 animals. The nutritional composition of feeding mixtures used in the course of monitoring complied with that of the commercial complete feeding mixtures produced in the Czech Republic, namely N1 (used until month 5 of the laying period) and N2 (from month 5 until the end of monitoring). The nutritional composition of both feeding mixtures (N1 and N2) is provided in Table 1. Group A hens were fed a mixture in which animal protein (fish meal) was replaced with plant-based protein, i.e. specially treated meal made of yellow lupin seed (the JUNO variety) at a level of 10\% (N1) and 6\% (N2), respectively. Lupin seed was treated using a special physicochemical method in a reactor at elevated temperature using calcium oxide under the commercial name "PROENERGOL". Group B hens received a mixture containing fish meal as the main source of nitrogen substances at a level of $10 \%(\mathrm{~N} 1)$, and $6 \%(\mathrm{~N} 2)$, respectively.

Table 1. Nutritional composition of feeding mixtures N1 and N2

\begin{tabular}{|c|c|c|c|c|}
\hline \multirow{2}{*}{$\begin{array}{l}\text { Nutritional } \\
\text { composition } \\
\left(\mathrm{g} \cdot \mathrm{kg}^{-1}\right)\end{array}$} & \multicolumn{2}{|c|}{ N1 } & \multicolumn{2}{|c|}{ N2 } \\
\hline & PROENERGOL & $\begin{array}{l}\text { Fish } \\
\text { meal }\end{array}$ & PROENERGOL & $\begin{array}{l}\text { Fish } \\
\text { meal }\end{array}$ \\
\hline Dry matter & 899.3 & 895.0 & 894.0 & 892.6 \\
\hline Crude protein & 185.0 & 185.0 & 161.5 & 162.8 \\
\hline Fat & 56.6 & 34.1 & 39.7 & 30.6 \\
\hline Fibre & 35.3 & 27.2 & 31.5 & 30.1 \\
\hline Nitrogen-free extract & 498.3 & 533.1 & 542.0 & 554.8 \\
\hline Starch & 345.5 & 421.6 & 420.1 & 441.6 \\
\hline Organic matter & 775.2 & 779.4 & 774.7 & 778.3 \\
\hline Ash & 124.1 & 115.6 & 119.3 & 114.3 \\
\hline $\mathrm{Ca}$ & 36.0 & 36.0 & 35.3 & 35.3 \\
\hline $\mathrm{P}$ & 7.2 & 7.7 & 6.3 & 6.3 \\
\hline $\mathrm{Mg}$ & 1.6 & 2.3 & 1.5 & 2.1 \\
\hline $\mathrm{Na}$ & 1.9 & 1.9 & 1.6 & 1.7 \\
\hline $\mathrm{K}$ & 7.1 & 6.4 & 6.2 & 6.1 \\
\hline Lys & 8.6 & 8.6 & 7.5 & 7.5 \\
\hline Met & 4.3 & 4.3 & 3.7 & 3.8 \\
\hline Thre & 6.2 & 6.2 & 5.6 & 5.5 \\
\hline Arg & 13.1 & 11.0 & 10.6 & 9.4 \\
\hline Ile & 6.8 & 6.6 & 5.8 & 5.7 \\
\hline $\mathrm{ME}\left(\mathrm{MJ} \cdot \mathrm{kg}^{-1}\right)$ & 11.7 & 11.7 & 11.3 & 11.3 \\
\hline
\end{tabular}

Eggs were collected at one-month intervals $(n=36)$. The experiment lasted 7 months. A total of 7 egg collections were carried out in the course of the experiment. A total of 252 eggs were subsequently analysed (Tables 2 -4) . 
After being separated from the white, the yolk was placed on a Petri dish (with a diameter of $50 \mathrm{~mm}$ ) and covered with a thin food foil. Then its colour was determined. Yolk colour was evaluated spectrophotometrically according to the CIELAB system using the portable spectrophotometer Superchroma S-Spex with the exclusion of gloss, by attaching the instrument on the foil perpendicularly. Prior to measurement, the instrument was calibrated to the food foil used. All measurements were performed three times. The resultant value represents the mean of the three values measured (Dvořák et al. 2005). The data collected every month were processed using statistical methods to yield values of the monitored parameters $\mathrm{L}^{*}, \mathrm{a}^{*}$, and $\mathrm{b}^{*}$ (Tables 2 - 4). Parameter $\mathrm{L}^{*}$ characterizes lightness ( 0 - black, 100 - white), parameter $\mathrm{a}^{*}$ describing a change in the wavelength in the red spectral region can reach a maximum in the bright red colour $(+120)$ or a minimum in the green-blue colour $(-80)$ and parameter $b^{*}$ represents transition from the yellow colour +120 to the blue-purple colour -80 . The effect of the feeding dose on yolk colour parameters was tested using the two-factor method ANOVA (MS EXCEL). The differences in particular month were tested using $t$-test. Variations in yolk parameters during the laying period were fitted with the $2^{\text {nd }}$ or $3^{\text {rd }}$ order polynomic functions (MS EXCEL).

\section{Results and Discussion}

The results are presented in Figs 1 - 3 and Tables 2 - 4. As seen in Table 2, statistically significant differences were found for parameter $\mathrm{L}^{*}$ in the lightness of yolk colour during four months of a total of seven months $(\alpha=0.05)$. The decrease in the mean value of parameter $\mathrm{L}^{*}$ (except for the beginning of the experiment) indicates that the colour of eggs turned dark. Parameter $L^{*}$ which characterizes lightness $(0$ - black, 100 - white) shows the largest difference in Month 5 of the laying period (56.945 and 60.557, respectively), which proves that the concentration of colour pigments in the egg yolk from hens fed a plant-based feed increased. Although parameter F ANOVA was close to the critical value for $\alpha=0.05$, this trend was not proven statistically significant. This result may be affected by the values measured in the beginning of the experiment (Fig. 1).

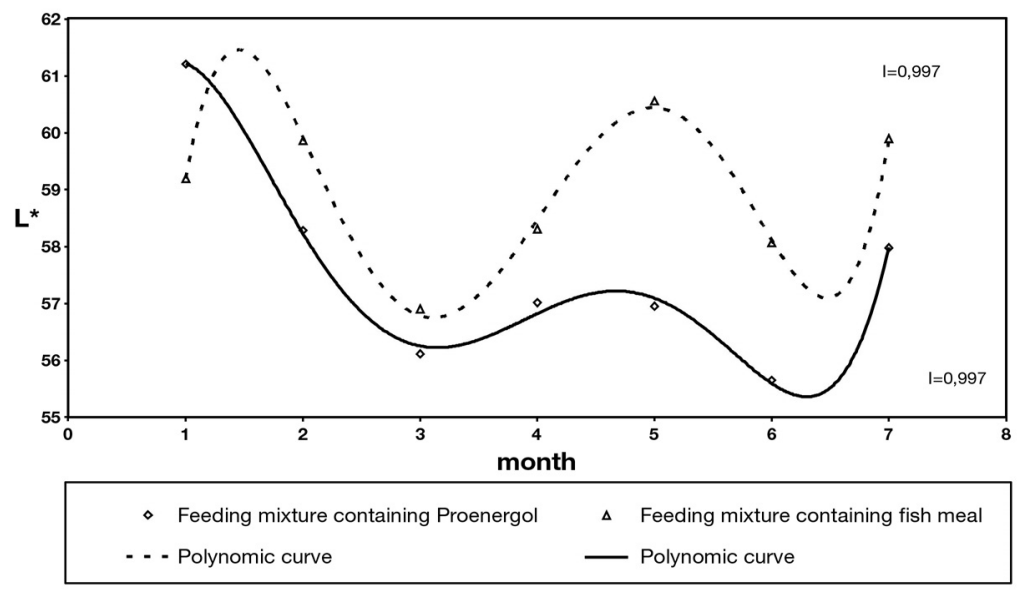

Fig. 1. Variation of yolk colour parameter $L^{*}$ with the composition of the feeding mixture

Parameter $\mathrm{a}^{*}$ describing the change in the wavelength in the red spectral region can reach a maximum in the bright red colour $(+120)$ or a minimum in the green-blue colour $(-80)$. When the feeding mixture for hens contained plant-based components, parameter a* increased significantly $(\alpha=0.05)$ during the whole period of monitoring (Table 3 ). The differences ranged from 1.1 to 3.9 (Fig. 2), which indicates an overall significant difference (ANOVA $\alpha=0.01$ ) between both curves at the given level of variability. Egg yolk from hens that received the mixture containing plant-based components (i.e. treated yellow lupin seed of the JUNO variety) had a distinct, red-orange colour, preferred by the consumers.

A statistically significant increase in parameter $b^{*}$ characterizing egg yolk colour was only 


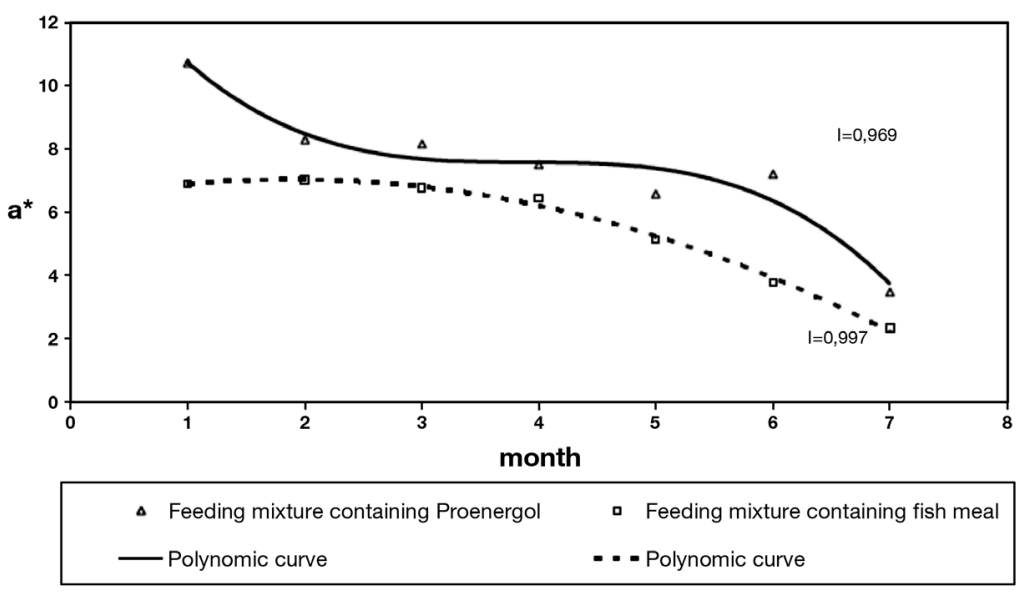

Fig. 2. Variation of yolk colour parameter a* with the composition of the feeding mixture

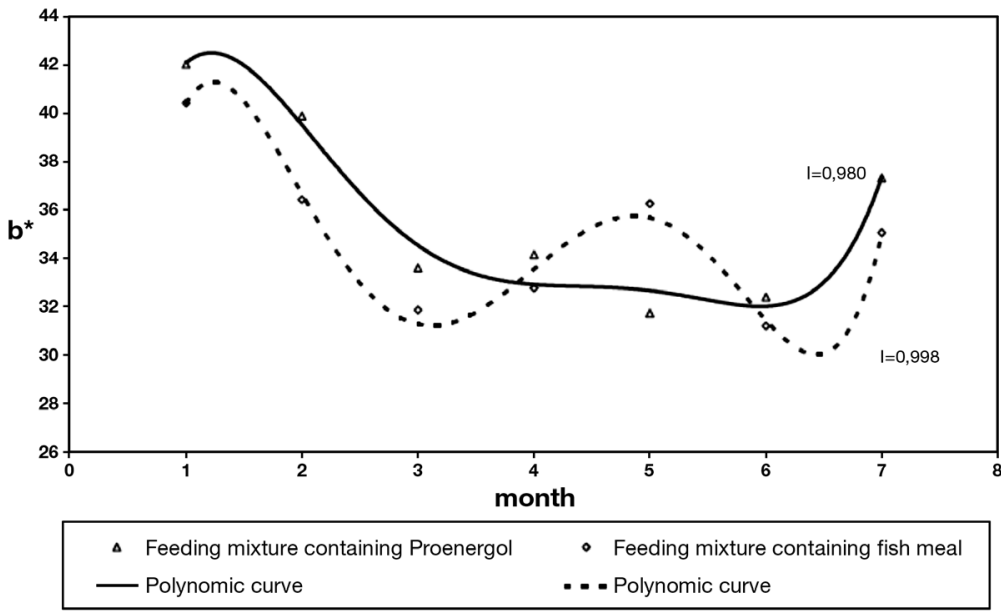

Fig. 3. Variation of yolk colour parameter $b^{*}$ with the composition of the feeding mixture

detected for one month (Table 4). Parameter $b *$ represents the transition from yellow colour +120 to blue-purple colour -80 . Its absolute value in this case influences the tone of red colour in relation to orange colour (values raging from 31 to 42 fall within the yellow region). Individual differences between both groups can be seen in Fig. 3. Comparison of both curves in the figure reveals the trend in the variation of parameter $b^{*}$ with the feeding dose. Except for the eggs collected in September (which showed the opposite trend), it was observed that the yolk tended to be of intensive yellow colour. However, the differences were not statistically conclusive $(\mathrm{F}=1.104$; Table 4$)$. Since consumers prefer orange-coloured yolk, it appears important to monitor parameter $\mathrm{a}^{*}$ rather than parameter $\mathrm{b}^{*}$.

It follows from the results that the supplementation of feed with lupin seed has a beneficial effect on the colour intensity of the egg yolk. Our results are in good agreement with the 
Table 2. Changes in yolk colour parameter $\mathrm{L}^{*}$ during individual months of the experiment

\begin{tabular}{|c|c|c|c|c|c|c|c|c|}
\hline $\mathrm{L}^{*}$ & Month & 1 & 2 & 3 & 4 & 5 & 6 & 7 \\
\hline \multirow[t]{4}{*}{ PROENERGOL } & $\mathrm{X}$ & $61.207+$ & 58.292 & 56.120 & 57.009 & 56.945 & 55.647 & 57.983 \\
\hline & $\mathrm{s}$ & 2.7474 & 2.7269 & 5.6757 & 4.3882 & 5.7183 & 4.8461 & 5.7014 \\
\hline & $\mathrm{R}$ & 11.89 & 11.55 & 21.08 & 16.62 & 20.04 & 20.55 & 21.56 \\
\hline & $\mathrm{s}_{\mathrm{X}}$ & 0.4644 & 0.4545 & 0.9459 & 0.7314 & 0.9530 & 0.8077 & 0.9637 \\
\hline \multirow[t]{6}{*}{ Fish meal } & $x$ & 59.196 & $59.873+$ & 56.895 & 58.306 & $60.557+$ & $58.071+$ & 59.904 \\
\hline & $\mathrm{s}$ & 3.0649 & 3.0497 & 5.4159 & 5.1595 & 3.7807 & 4.6189 & 5.7680 \\
\hline & $\mathrm{R}$ & 11.65 & 14.98 & 21.01 & 23.84 & 17.94 & 22.85 & 19.17 \\
\hline & $S_{X}$ & 0.5181 & 0.5083 & 0.9027 & 0.8599 & 0.6301 & 0.7098 & 0.9892 \\
\hline & $\mathrm{F}(1.6)$ & 4.326 & & & & & & \\
\hline & $\begin{array}{c}F_{\text {crit }} \\
(\alpha=0.05)\end{array}$ & 5.987 & & & & & & \\
\hline
\end{tabular}

$\mathrm{x} \quad$..... Arithmetic mean

s....... Standard deviation

$\mathbf{s}_{\mathrm{x}}$...... Standard deviation of the mean

R....... Range of variation $\left(\mathrm{x}_{\max }-\mathrm{x}_{\min }\right)$

$+\ldots$... Statistically significant difference among means $(\alpha<0.05)++(\alpha<0.01)$

F...... ANOVA parameter

Table 3. Changes in yolk colour parameter a* during individual months of the experiment

\begin{tabular}{|c|c|c|c|c|c|c|c|c|}
\hline$a^{*}$ & Month & 1 & 2 & 3 & 4 & 5 & 6 & 7 \\
\hline \multirow[t]{4}{*}{ PROENERGOL } & $\mathrm{x}$ & $10.734+$ & $8.293+$ & $8.161+$ & $7.502+$ & $6.572+$ & $7.197+$ & $3.460+$ \\
\hline & $\mathrm{S}$ & 2.0769 & 1.7942 & 1.5896 & 1.5109 & 1.5631 & 1.5054 & 1.1572 \\
\hline & $\mathrm{R}$ & 9.29 & 7.29 & 5.85 & 6.4 & 6.6 & 7.08 & 5.77 \\
\hline & $\mathrm{s}_{\mathrm{X}}$ & 0.3511 & 0.2990 & 0.2649 & 0.2518 & 0.2605 & 0.2509 & 0.1956 \\
\hline \multirow[t]{5}{*}{ Fish meal } & $\mathrm{x}$ & 6.882 & 7.019 & 6.755 & 6.431 & 5.125 & 3.750 & 2.316 \\
\hline & $\mathrm{S}$ & 2.0686 & 2.1248 & 1.9050 & 1.7247 & 1.4339 & 1.3223 & 0.8687 \\
\hline & $\mathrm{R}$ & 8.04 & 9.47 & 8.08 & 7.43 & 5.32 & 7.64 & 4.73 \\
\hline & $\mathrm{s}_{\mathrm{X}}$ & 0.3497 & 0.3541 & 0.3175 & 0.2874 & 0.2390 & 0.2204 & 0.1490 \\
\hline & $\mathrm{F}(1.6)$ & $19.226+$ & & & & & & \\
\hline$(\alpha=0.05)$ & $\begin{array}{c}F_{\text {crit }} \\
5.987\end{array}$ & & & & & & & \\
\hline
\end{tabular}

x ...... Arithmetic mean

s....... Standard deviation

$\mathbf{s}_{\mathrm{x}}$.... Standard deviation of the mean

R....... Range of variation $\left(x_{\max }-x_{\min }\right)$

$+\ldots \ldots$. Statistically significant difference among means $(\alpha<0.05)$

F...... ANOVA parameter

findings reported by Watkin s et al. (1987) who studied changes in the colour of egg yolk from layers fed a feed supplemented with lupin seed at a level of $10 \%$ and $20 \%$. These authors found that eggs laid by layers receiving the mixture supplemented with lupin seed had more intensive colour shades. The authors drew the conclusion that lupin can be considered a suitable source of pigments in egg yolk. Similar conclusions were also published by Francesch (1993). However, authors such as Prinsloo et al. (1992) and Quarantelli (1993) failed to prove a positive effect of lupin on the yolk colour. The abovementioned differences in the conclusion regarding the yolk colour may are due to the fact that the tested feeding mixtures for laying hens contained seed from different lupin varieties with different levels of pigments.

As a conclusion, suitably designed vegetable feeds can be used to improve the quality 
Table 4. Changes in yolk colour parameter $b^{*}$ during individual months of the experiment

\begin{tabular}{|c|c|c|c|c|c|c|c|c|}
\hline$b^{*}$ & Month & 1 & 2 & 3 & 4 & 5 & 6 & 7 \\
\hline \multirow[t]{4}{*}{ PROENERGOL } & $\mathrm{x}$ & 42.029 & $39.897+$ & 33.603 & 34.148 & 31.716 & 32.376 & 37.331 \\
\hline & $\mathrm{s}$ & 3.3845 & 4.2634 & 4.0844 & 4.8672 & 4.0941 & 4.5385 & 6.2777 \\
\hline & $\mathrm{R}$ & 13.81 & 14.73 & 15.09 & 24.07 & 16.74 & 17.91 & 29.23 \\
\hline & $S_{X}$ & 0.5721 & 0.7106 & 0.6807 & 0.8112 & 0.6824 & 0.7564 & 1.0611 \\
\hline \multirow[t]{6}{*}{ Fish meal } & $\mathrm{x}$ & 40.433 & 36.418 & 31.846 & 32.764 & $36.252+$ & 31.191 & 35.057 \\
\hline & $\mathrm{s}$ & 3.9217 & 4.4086 & 5.9526 & 4.2189 & 4.5730 & 4.3685 & 4.0868 \\
\hline & $\mathrm{R}$ & 14.98 & 18.43 & 26.5 & 19.56 & 22.19 & 16.62 & 17.39 \\
\hline & $S_{x}$ & 0.6629 & 0.7348 & 0.9921 & 0.7032 & 0.7622 & 0.7281 & 0.7009 \\
\hline & $F(1.6)$ & 1.105 & & & & & & \\
\hline & $\begin{array}{c}\mathrm{F}_{\text {crit }} \\
(\alpha=0.05)\end{array}$ & 5.987 & & & & & & \\
\hline
\end{tabular}

$\mathrm{x} \quad$.... Arithmetic mean

s....... Standard deviation

$\mathbf{s}_{\mathrm{x}} \quad \ldots$ Standard deviation of the mean

$\mathrm{R}$........ Range of variation $\left(\mathrm{x}_{\max }-\mathrm{x}_{\min }\right)$

$+\ldots$.... Statistically significant difference among means $(\alpha<0.05)$

F...... ANOVA parameter

parameters of eggs, particularly the yolk colour, in order to respond to consumer preference of a distinct orange colour of the egg yolk and to comply with food safety requirements at the same time.

\section{Barva vaječného žloutku v závislosti na složení krmné směsi pro nosnice}

Cílem tohoto článku bylo ověřit, zda je možné nahradit rybí moučku speciálně ošetřeným šrotem vyrobeným ze semen lupiny žluté, a to ve vztahu k barvě žloutku. Experiment byl realizován na 72 nosnicích, které byly rozděleny do dvou skupin. Pokusné skupině 36 nosnic byla podávána krmná směs, ve které byl šrot ze semen lupiny žluté (odrůda JUNO) použit jako náhrada za rybí moučku, která byla použita jako animální proteinová komponenta v krmných směsích u kontrolní skupiny. Po dobu sedmi měsíců, v měsíčních intervalech, byly u obou skupin odebírány vzorky vajec pro měření barvy vaječného žloutku.

Stanovení barvy žloutku se provádělo novou spektrofotometrickou metodou, která vychází ze systému CIELAB. Pomocí přenosného spektrofotometru bylo prováděno měření s vyloučením lesku. Statisticky průkazný pokles průměrné hodnoty parametru $L^{*}(\alpha=0,05)$ prokázal ztmavnutí vajec. U parametru a* došlo ke statisticky průkaznému nárůstu( ANOVA $\alpha=0,01$ ), v jednotlivých měsících došlo ke změně z 1,1 na 3,9. Žloutky měly výraznější červenooranžovou barvu. Parametr $b^{*}$ nevykazoval žádný statistický rozdíl, přesto barva žloutku inklinovala ke žluté barvě.

Přítomnost šrotu ze semen lupiny žluté v krmné dávce vedlo k výrazně žlutočervenější barvě vaječného žloutku.

\section{Acknowledgements}

This research was carried out in the frameworks of the Research Plan of the Ministry of Education, Youth and Physical Training of the Czech Republic MSM6215712402 "Veterinary Aspects of Food Safety and Quality".

\section{References}

Act No. 91/1996 Coll., concerning feed. Ministry of Interior, Prague, Czech Republic, pp. 1064-1071

The Regulation of the Ministry of Agriculture No. 451/2000 Coll. through which Act No. 91/1996 Coll. concerning feed, as amended by Act No. 244/2000 Coll., is implemented. Ministry of Interior, Prague, Czech Republic, pp. 6601-6616 
BAIN MM 1992: Egg shell strength: A relationship between the mechanism of failure end the ultrastructural organisation of the mammilary layer. Brit Poultry Sci 33: 303-319

CIE (1986): Colorimetry, $2^{\text {nd }}$ edn., CIE Publications No. 15.2. Commission Internationale de l'Eclaraige, Vienna.

DVOŘ́K P, MUSILOVÁ H, ŠVARCOVÁ I 2001: On-line Measurements of Colour of Pork. Fleischwirtschaft 81: $89-91$

DVOŘÁK P, KUNOVÁ J, STRAKOVÁ E, SUCHÝ P, KUNOVÁ V 2005: Changes in the colour and the acidity number of egg yolk upon irradiation. Eur Food Res Technol 221: 348-352

FRANCESCH M 1993: Utilisation of bitter lupins by laying hens. Proceedings of the Second International Workshop Recent advances of research in antinutritional factors in legume seeds, Wageningen Press, Wageningen, pp. 363-366

HALAJ M, BENKOVÁ J, BAUMGARTNER J 1998: Parameters of hen egg quality in various breeds and strains. Czech J Anim Sci 43: 375- 378

LEESON S, SUMMERS JD 1997: Commercial Poultry Nutrition, $2^{\text {nd }}$ edn., University Books, Guelph, Ontario, Canada, $350 \mathrm{p}$.

PRINSLOO JJ, SMITH GA, RODE W 1992: Sweet white Lupinus albus (cv Buttercup) as a feedstuff for layers. Brit Poultry Sci 33: 525-530

QUARANTELLI A 1993: Composition of white lupin seed meal (Lupinus albus, L.) and its use in feeding laying hens. In: Proceedings of the $10^{\text {th }}$ national congress. Scientific Association of Animal Production, Bologna, pp. 499-505

SURAI PF, IONOV IA, KUKLENKO TV, KOSTJUK IA, MAC PHERSON A, SPEAKE BK, NOBLE RC, SPARKS NH 1998: Effects of Supplementing the Hens Diet with Vitamin A on the Accumulation of Vitamin A and E, Ascorbic Acid and Carotenoids in the Egg Yolk and the Embryonic Liver. Brit Poultry Sci 39: 257-263

TƯMOVÁ E, EBEID T 2005: Effect of time of oviposition on egg quality characteristics in a litter housing system. Czech J Anim Sci 50: 129-134

WATKINS BA, MIROSH L, WHITE W1987: Lupin as a protein source for layers. Poultry Sci 66: 1798-1806 